\title{
From the Editors
}

This special focus issue, guest edited by Jutta $\mathrm{H}$ elm, features articles on German cities and urban politics. We are delighted to furnish $\mathrm{Helm}$ and her colleagues with a forum to publish their research on a crucial area of modern German politics and society. Additionally, we invited Russell Dalton, a member of our editorial board and among the most distinguished experts on German elections, to offer his keen insights on Germany's landmark parliamentary election in September 1998. We hope you enjoy the issue. 